\title{
Toxicant effects on the zoospore stage of the marine macroalga Ecklonia radiata (Phaeophyta: Laminariales)
}

\author{
Joseph R. Bidwell ${ }^{1, *}$, Karen W. Wheeler ${ }^{2}$, Trevor R. Burridge ${ }^{3}$

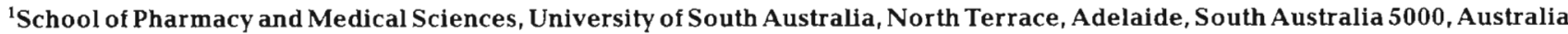 \\ ${ }^{2}$ Department of Environmental Management, Edith Cowan University, Joondalup, Western Australia 6027, Australia \\ ${ }^{3}$ Department of Biological Sciences, Victoria University of Technology, PO Box 14428, MCMC, Victoria 3001, Australia
}

\begin{abstract}
Marine macroalgae provide both food and habitat for a range of other organisms in nearshore coastal areas. The effect of contaminants upon macroalgae is therefore an important aspect to consider in the regulation of marine effluent discharges. Unfortunately, a lack of standardized bioassay protocols has limited the extent to which macroalgae have been used in routine toxicity testing. In the present study, the effect of selected reference toxicants (hexavalent chromium, copper and zinc) upon germination and growth of zoospores of the marine macroalga Ecklonia radiata (C.Ag.) J.Ag. was investigated in $48 \mathrm{~h}$ bioassays. E. radiata is often a dominant member of near-shore subtidal communities in temperate Australia, New Zealand and South Africa, regions in which toxicological data for native species are lacking. Release of zoospores was induced in the laboratory and settled spores were exposed to the metals. Zoospores from 3 different populations in Western Australia and 1 population in Victoria were tested to evaluate geographic variation in response. There were no significant differences in $48 \mathrm{~h} \mathrm{EC}_{50}$ values between the populations tested. At $20^{\circ} \mathrm{C}, \mathrm{EC}_{50}$ values for germination ranged between 54.9 and $65.1 \mathrm{mg} \mathrm{l}^{-1}$ for chromium, 320 and $470 \mu \mathrm{g} \mathrm{l}^{-1}$ for copper and 18.1 and $18.6 \mathrm{mg} \mathrm{l}^{-1}$ in 2 bioassays conducted with zinc. Germination of control zoospores was greater than $90 \%$ in all bioassays. Germination tube growth was the more sensitive of the 2 endpoints examined. $\mathrm{EC}_{50}$ values for growth ranged between 31.8 and $47.5 \mathrm{mg} \mathrm{l}^{-1}$ for chromium and 180 and $210 \mu \mathrm{g} \mathrm{l}^{-1}$ for copper. Coefficients of variation for $\mathrm{EC}_{50}$ values from tests with chromium or copper were between 24 and $47 \%$ for germination and 11 and $54 \%$ for germination tube growth. With its wide distribution, ecological significance and simple bioassay methodology, E. radiata is well suited for use in routine marine toxicity testing.
\end{abstract}

KEY WORDS: Macroalga $\cdot$ Toxicity test $\cdot$ Ecklonia $\cdot$ Germination $\cdot$ Australia

\section{INTRODUCTION}

Marine environments in developed coastal areas commonly receive discharges from a range of industrial and municipal sources. If the integrity of coastal marine systems is to be maintained, the discharge of this waste must be effectively monitored and regulated. It is widely recognized that this regulation should rely on biological effects data (from laboratory toxicity tests or field studies) in addition to the chemi-

\footnotetext{
•E-mail: j.bidwell@unisa.edu.au
}

cal criteria which have been used in the past to set discharge limits (Cairns \& Pratt 1989).

Toxicity tests have been more commonly used to investigate the effects of effluent discharges in freshwater systems, with marine and estuarine bioassay protocols available for only a few species of phytoplankton, crustaceans and fish (Richardson \& Martin 1994). The application of these bioassays to regions in which the test organisms are not endemic has been criticized, and the need to expand the range of marine test methods to include more locally relevant species has been identified (Anderson et al. 1990). 
Marine macroalgae have only recently been used in routine toxicity testing and bioassay protocols are limited (Thursby \& Steele 1995). The majority of these tests focus on germination of early life stages or sexual reproduction. Macroalgae are ecologically important to many near-shore marine communities, providing food and habitat to a range of other marine organisms. Tests using these algae are both sensitive and relatively easy to conduct.

This paper describes a bioassay method which utilizes the zoospore stage of the brown alga Ecklonia radiata (C.Ag.) J.Ag. (Phaeophyta: Laminariales). E. radiata is a common subtidal species in temperate Australia, a region in which toxicity data for native aquatic species is generally lacking. In an adaptation of bioassay methods initially developed for the giant kelp Macrocystis pyrifera (Anderson \& Hunt 1988), germination and initial growth of $E$. radiata zoospores were used as endpoints in $48 \mathrm{~h}$ bioassays with hexavalent chromium, copper and zinc.

\section{METHODS}

Zoospore release. Like Macrocystis pyrifera, Ecklonia radiata exhibits a heteromorphic alteration of generations, with free swimming haploid zoospores released from a diploid sporophyte. Zoospores were obtained as described by Jennings (1967) and Novaczek (1984). Fertile blades of E. radiata (as determined by the presence of spore-producing sori) were collected by SCUBA divers from 8 to 10 plants in each of the populations sampled. The blades were wrapped in moist paper towel and transported back to the laboratory on ice. In the laboratory, the blades were rinsed with freshwater and sections containing sori were cut into segments of approximately $4 \times 4 \mathrm{~cm}$. These sections were dried at room temperature $\left(20\right.$ to $\left.23^{\circ} \mathrm{C}\right)$ for $30 \mathrm{~min}$ and placed in filtered $(1 \mu \mathrm{m})$ seawater for 10 min. During this initial soaking, the kelp may produce a copious amount of mucilage; this was removed by lightly brushing the frond segments. Release of zoospores was initiated by an additional soaking in fresh seawater for $30 \mathrm{~min}$ at $20^{\circ} \mathrm{C}$. Maximum zoospore release occurred during this second phase of soaking. Zoospore density was monitored with a hemocytometer and, upon reaching 20000 spores $\mathrm{ml}^{-1}$, the blade sections were removed. The remaining 'zoospore solution' was filtered through a $10 \mu \mathrm{m}$ mesh before initiating the bioassay.

Bioassay protocol. The bioassay protocol is similar to that developed for Macrocystis pyrifera by Anderson \& Hunt (1988). Tests were conducted in $100 \mathrm{ml}$ polyethylene cups which contained a glass coverslip on which zoospores would settle, germinate and grow.
Four replicate chambers were used for each toxicant concentration and the control. Bioassays were initiated by placing $20 \mathrm{ml}$ of the zoospore solution into each of the test chambers. After $1 \mathrm{~h}$ to allow the zoospores to settle, the remaining solution was removed and $20 \mathrm{ml}$ of test solution was added. Removal of the zoospore solution significantly reduced the amount of debris which accumulated on the coverslip and facilitated scoring settled zoospores at the end of the test. Bioassays were run for $48 \mathrm{~h}$ at $20 \pm 1^{\circ} \mathrm{C}$ in a constant temperature water bath. Illumination was maintained on a 12:12 h light:dark cycle with cool white fluorescent tubes $\left(110 \mu \mathrm{E} \mathrm{m}^{-2} \mathrm{~s}^{-1}\right)$. At the end of the test period, the coverslips were removed and 50 randomly selected zoospores were scored for the presence of a germination tube using a compound light microscope at a magnification of 200x. An additional 10 zoospores were randomly selected on each cover slip and their germination tubes were measured to the nearest $0.1 \mu \mathrm{m}$ with an ocular micrometer. Criteria used to assess germination was development of a germination tube which was at least 1 spore radius in length $(\sim 1.5 \mu \mathrm{m})$. This is consistent with methods used to assess germination in Macrocystis spp. (Anderson \& Hunt 1988, Burridge et al. 1996). Bioassays were conducted between April and October of 1995.

Interpopulation variability. In order to assess differences in sensitivity between isolated populations of Ecklonia radiata, sporophytes were collected from 4 different Australian populations: North Mole, located in Fremantle, Western Australia (WA) (32 $3^{\circ} \mathrm{S}, 115^{\circ} 43^{\prime} \mathrm{E}$ ); Cottesloe, WA $\left(31^{\circ} 59^{\prime} \mathrm{S}, 115^{\circ} 44^{\prime} \mathrm{E}\right)$; North Beach, WA $\left(31^{\circ} 51^{\prime} \mathrm{S}, 115^{\circ} 45^{\prime} \mathrm{E}\right)$; and Queenscliff, Victoria $\left(38^{\circ}\right.$ $\left.16^{\prime} \mathrm{S}, 144^{\circ} 39^{\prime} \mathrm{E}\right)$. The Western Australian populations were at least $2 \mathrm{~km}$ apart. Based on local currents along that part of the coast, it is highly unlikely that exchange of zoospores occurred between the populations.

Test solutions. Toxicant stock solutions $\left(1000 \mathrm{mg} \mathrm{l}^{-1}\right)$ were prepared with analytical grade (Aldrich Chemicals) hexavalent chromium $\left(\mathrm{K}_{2} \mathrm{Cr}_{2} \mathrm{O}_{7}\right)$, copper $\left(\mathrm{CuSO}_{4}\right)$ and zinc $\left(\mathrm{ZnSO}_{4}\right)$. Filtered seawater was used as the diluent in all tests. For the bioassays conducted in Western Australia, seawater was collected from Marmion Marine Park and stored in a $1000 \mathrm{l}$ fibreglass tank prior to use. Seawater used for the Queenscliff tests was collected near the Queenscliff Marine Laboratories and similarly stored. Dissolved oxygen, $\mathrm{pH}$, salinity and temperature were measured in each test concentration at the start and end of the bioassays and ranged from 7 to $8 \mathrm{mg} \mathrm{l}^{-1}, 7.4$ to $8.1,34$ to 35 and 20 to $22.5^{\circ} \mathrm{C}$, respectively.

Statistical analyses. Data were expressed as a proportion of the control and $\mathrm{EC}_{50}$ values (concentration of toxicant causing an effect on $50 \%$ of the test population) were generated using the trimmed Spearman- 
Karber method (Hamilton et al. 1983). The No Observed Effect Concentration (NOEC) was calculated as the highest concentration in which either germination or growth were not significantly different from the control at $\alpha=0.05$. To determine the NOEC, percent germination data were arcsine transformed prior to analysis of variance (ANOVA). Multiple comparison to determine differences between control and treatments was conducted using Dunnett's tests (Zar 1984).

\section{RESULTS}

Zoospores began to settle onto the glass coverslips within $1 \mathrm{~h}$ of release and noticeable growth of the germination tubes was evident within 4 to $6 \mathrm{~h}$. After $48 \mathrm{~h}$ germination success of zoospores was greater than $90 \%$ in controls and average germ tube length was 9 to $11 \mu \mathrm{m}$ (Fig. 1). Based on these observations, it was determined that a $48 \mathrm{~h}$ test period was suitable to allow measurable change in either endpoint under the test conditions described.

Based on comparison of $\mathrm{EC}_{50}$ values and associated confidence intervals, there were no significant differences in sensitivity to chromium or copper between the Ecklonia radiata populations tested, regardless of

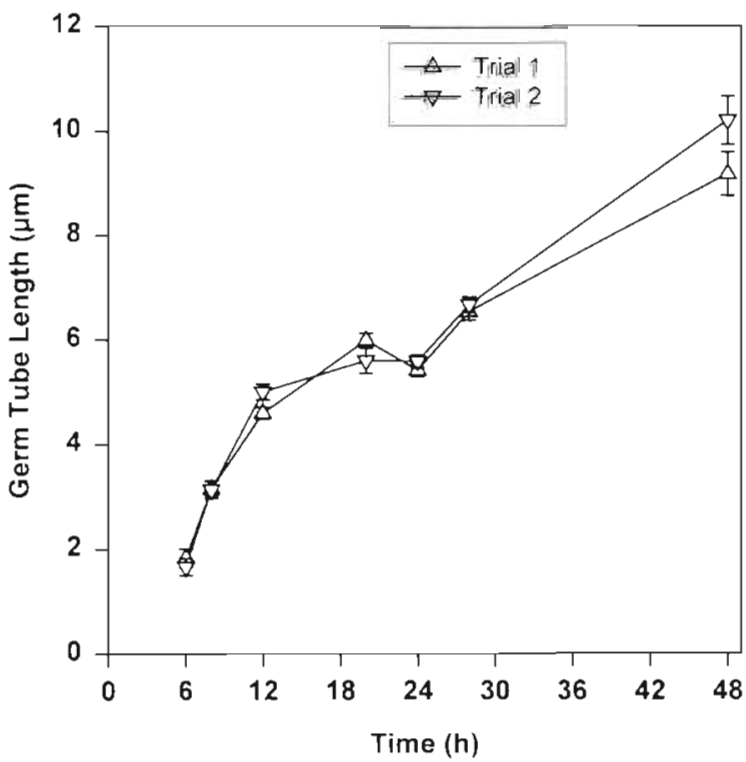

Fig. 1. Ecklonia radiata. Growth of germination tubes over $48 \mathrm{~h}$. Each point is the average of 10 replicate measurements Error bars $= \pm 1$ SEM

which endpoint was used (Tables 1 \& 2). In bioassays with chromium, average $48 \mathrm{~h} \mathrm{EC}_{50}$ values for germination ranged between 54.9 and $65.1 \mathrm{mg} \mathrm{l}^{-1}$, while those

Table 1. Ecklonia radiata. Mean $48 \mathrm{~h} \mathrm{EC}_{50}$ values for germination and growth of zoospores exposed to hexavalent chromium

\begin{tabular}{|llcccc|}
\hline Location & Endpoint & $\begin{array}{c}\text { Mean EC } \\
\left(\mathrm{mg} \mathrm{l}^{-1}\right)\end{array}$ & $\begin{array}{c}95 \% \text { confidence } \\
\text { interval }\end{array}$ & Range & $\begin{array}{c}\text { Coefficient of } \\
\text { variation }(\%)\end{array}$ \\
\hline North Mole, WA & Germination & 58.3 & $46.7-70.0$ & $44.2-80.7(\mathrm{n}=7)$ & 24 \\
& Growth & 31.8 & $1.1-62.5$ & $16.4,47.2(\mathrm{n}=2)$ & - \\
North Beach, WA & Germination & 57.0 & $42.3-71.7$ & $19.3-76.9(\mathrm{n}=10)$ & 37 \\
& Growth & 47.5 & $42.7-52.3$ & $39.4-56.8(\mathrm{n}=7)$ & 12 \\
Cottesloe, WA & Germination & 54.9 & $40.0-69.8$ & $40.0-81.3(\mathrm{n}=5)$ & 27 \\
Queenscliff, Vic. & Growth & 46.9 & $17.5-76.3$ & $10.5-82.4(\mathrm{n}=4)$ & 54 \\
& Germination & 65.1 & $49.0-80.4$ & $31.5-97.8(\mathrm{n}=12)$ & 30 \\
& Growth & & Not measured & & \\
\end{tabular}

Table 2. Ecklonia radiata. Mean $48 \mathrm{~h} \mathrm{EC}_{50}$ values for germination and growth of zoospores exposed to copper

\begin{tabular}{|c|c|c|c|c|c|}
\hline Location & Endpoint & $\begin{array}{c}\text { Mean EC } \\
\left(\mu \mathrm{gl}^{-1}\right)\end{array}$ & $\begin{array}{c}95 \% \text { confidence } \\
\text { interval }\end{array}$ & Range & $\begin{array}{l}\text { Coefficient of } \\
\text { variation }(\%)\end{array}$ \\
\hline North Mole, WA & $\begin{array}{l}\text { Germination } \\
\text { Growth }\end{array}$ & $\begin{array}{l}443 \\
200\end{array}$ & $\begin{array}{l}391-584 \\
140-261\end{array}$ & $\begin{array}{l}160-776(\mathrm{n}=9) \\
151-292(\mathrm{n}=3)\end{array}$ & $\begin{array}{l}29 \\
30\end{array}$ \\
\hline North Beach, WA & $\begin{array}{l}\text { Germination } \\
\text { Growth }\end{array}$ & $\begin{array}{l}351 \\
180\end{array}$ & $\begin{array}{l}252-472 \\
160-200\end{array}$ & $\begin{array}{l}193-657(\mathrm{n}=9) \\
120-221(\mathrm{n}=6)\end{array}$ & $\begin{array}{l}47 \\
11\end{array}$ \\
\hline Cottesloe, WA & $\begin{array}{l}\text { Germination } \\
\text { Growth }\end{array}$ & $\begin{array}{l}470 \\
210\end{array}$ & $\begin{array}{l}331-605 \\
140-290\end{array}$ & $\begin{array}{l}210-730(n=5) \\
127-341(n=4)\end{array}$ & $\begin{array}{l}32 \\
34\end{array}$ \\
\hline Queenscliff, Vic. & $\begin{array}{l}\text { Germination } \\
\text { Growth }\end{array}$ & 320 & $\begin{array}{c}210-440 \\
\text { Not measured }\end{array}$ & $200-538(n=12)$ & 37 \\
\hline
\end{tabular}


for germ tube growth ranged between 31.8 and $47.5 \mathrm{mg} \mathrm{l}^{-1}$ (Table 1). While the $\mathrm{EC}_{50}$ values for growth in these tests were consistently lower than the corresponding values for germination, confidence intervals for the 2 endpoints did overlap (Table 1).

The zoospores were significantly more sensitive to copper than chromium. Average $48 \mathrm{~h} \mathrm{EC}_{50}$ values for germination in the copper bioassays ranged between 320 and $470 \mu \mathrm{g} \mathrm{I}^{-1}$ (Table 2). Growth of the germination tube was again the more sensitive endpoint, with $\mathrm{EC}_{50}$ values ranging between 180 and $210 \mu \mathrm{g} \mathrm{l}^{-1}$. In these tests, confidence intervals did not overlap with those of the corresponding germination value.

Coefficients of variation $(\mathrm{CV}=$ standard deviation/ mean $\times 100 \%$ ) for the $\mathrm{EC}_{50}$ values generated from the chromium bioassays ranged from 24 to $37 \%$ and 12 to $54 \%$ for germination and growth, respectively. For the copper tests, CVs ranged from 29 to $47 \%$ for germination and 11 to $34 \%$ for growth.

Combined test data from each population were used to generate the concentration-response curves shown in Fig. 2. Some between-population differences in
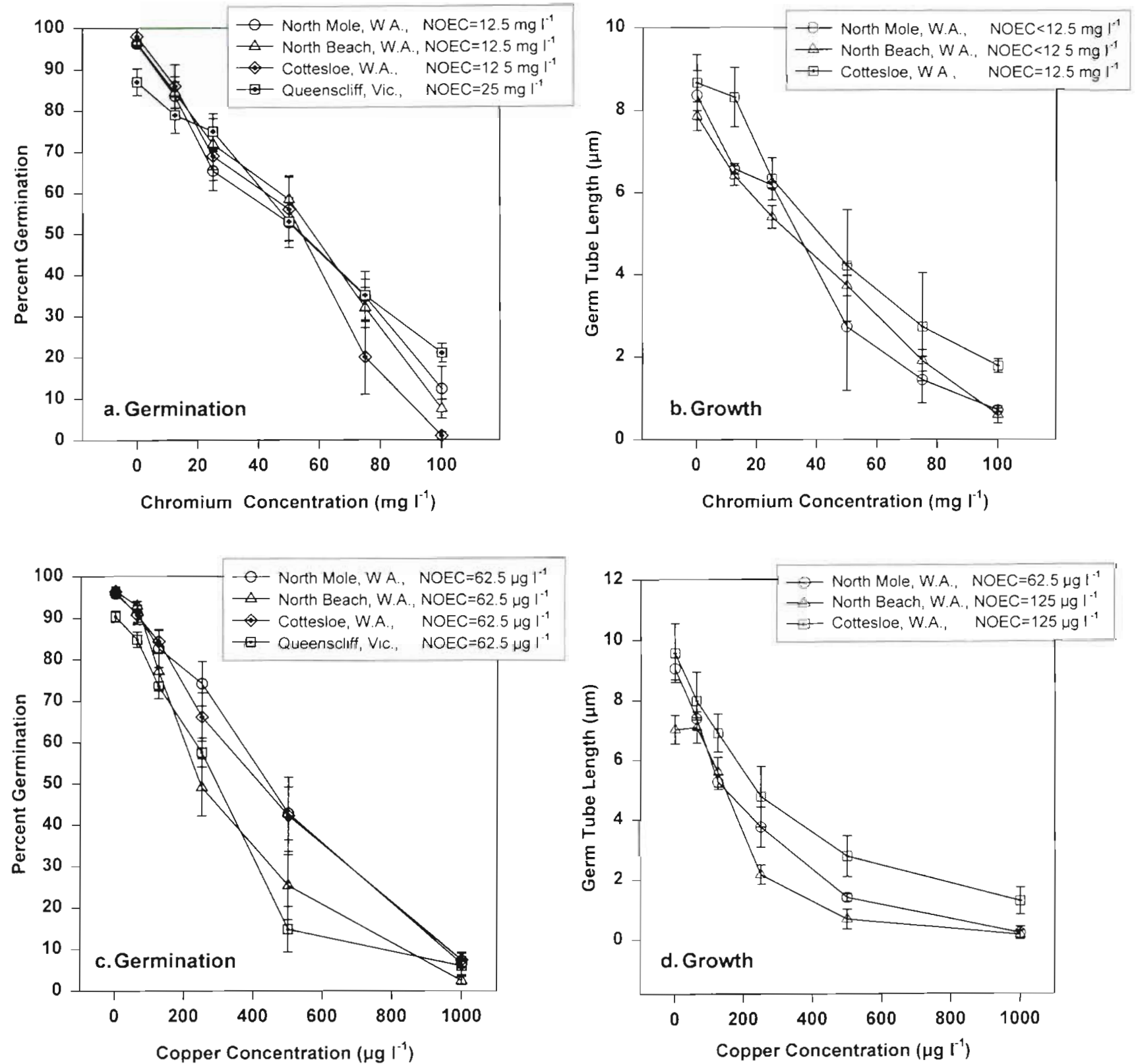

Fig. 2. Ecklonia radiata. Response curves for $(\mathrm{a}, \mathrm{c})$ germination and (b, d) growth of zoospores in bioassays with (a, b) chromium and $(\mathrm{c}, \mathrm{d})$ copper. Each point represents the average value for all bioassays conducted with the population. Error bars $= \pm 1 \mathrm{SEM}$ 
response to the reference toxicants became apparent when comparing NOEC values. For example, the NOEC for germination in the chromium bioassay was $12.5 \mathrm{mg} \mathrm{l}^{-1}$ for the 3 Western Australian populations and $25 \mathrm{mg} \mathrm{l}^{-1}$ for the Queenscliff, Victoria tests (Fig. 2a). The NOEC for germination tube growth in the chromium tests was $<12.5 \mathrm{mg} \mathrm{l}^{-1}$ for the North Mole and North Beach zoospores and $12.5 \mathrm{mg} \mathrm{l}^{-1}$ for those from Cottesloe (Fig. 2b). For bioassays with copper, the NOEC for germination was $62.5 \mathrm{\mu g} \mathrm{l}^{-1}$ for all 4 populations, although variability between the populations increased at the intermediate test concentrations (Fig. 2c). The germination tube growth data from the copper bioassays were confounded to some degree by the high variability in the lower metal concentrations of the Cottesloe and North Beach tests. In some bioassays, growth of the germ tube was stimulated at $62.5 \mu \mathrm{g} \mathrm{l}^{-1}$, while in other tests growth was depressed as compared to controls. The North Beach data were also affected by reduced growth in some of the control trials. This led to a reduced average germ tube length for the combined controls (Fig 2d). The NOEC for copper tests from Cottesloe and North Beach was $125 \mu \mathrm{g}$ $\mathrm{I}^{-1}$, while that for the North Mole tests was $62.5 \mathrm{\mu g} \mathrm{l}^{-1}$ (Fig. 2d).

Two bioassays with zinc were conducted with zoospores from the North Mole. In these tests, $48 \mathrm{~h}$ $\mathrm{EC}_{50}$ values of 18.1 (16.8 to $18.9,95 \%$ confidence interval) and $18.6 \mathrm{mg} \mathrm{l}^{-1}$ (17.7 to 21.3$)$ were generated in these tests. The NOEC was $6.25 \mathrm{mg} \mathrm{l}^{-1}$ in both tests.

\section{DISCUSSION}

The pattern of settlement and growth of Ecklonia radiata zoospores in the present study was similar to that observed by Jennings (1967), who reported settling and formation of germination tubes within $6 \mathrm{~h}$ of release and growth of the germ tubes to approximately $10 \mu \mathrm{m}$ within $48 \mathrm{~h}$. Zoospores of Macrocystis pyrifera appear to grow faster than those of E. radiata, attaining germination tube lengths of 14 to $17 \mu \mathrm{m}$ in $48 \mathrm{~h}$ (Anderson \& Hunt 1988, Anderson et al. 1990, Pillai et al. 1992).

\section{Interpopulation variability}

When germination and growth data were expressed as a percentage of the controls and analyzed by regression to produce an $\mathrm{EC}_{50}$, there were no significant differences in response to the reference toxicants between the 4 populations of Ecklonia radiata sampled. In a similar study which examined the effect of copper on germination and growth of zoospores from
Macrocystis pyrifera, Anderson et al. (1990) also observed general agreement in the responses of 4 populations of kelp collected off the California coast (USA), In their study, some of the inter-population variability was attributed to longer storage of sporophylls from one of the populations examined.

Differences in NOEC values and levels of variability in response to certain metal concentrations were observed between the Ecklonia radiata populations examined in the present study. Previous exposure to contaminants and/or differences in water quality could affect the performance of organisms which are collected from the field and used in toxicity tests. With regard to $E$. radiata, differential survival of zoospores, gametophytes or young sporophytes due to the selection pressure imposed by toxicants could ultimately lead to a more resistant population of kelp which responds differently in toxicity tests than a corresponding population in cleaner water. Genetically based variation in tolerance to contaminants has been observed in a number of different taxa, including macroalgae (Hall et al. 1981, Reed \& Moffat 1983, Nevo et al. 1986, Chagnon \& Guttman 1989). When using field-collected organisms in bioassays to develop site-specific regulations, prior exposure to pollutants is one of the factors which becomes integrated in the response of the resident population being examined. However, this issue obviously becomes more critical when the goal is to standardize test protocols and assess inter-laboratory variation in bioassay results.

\section{Intrapopulation variability}

Environment Canada (1990) recommends frequent testing with reference toxicants when developing test protocols with new organisms, stating that a desirable level of consistency is indicated by a coefficient of variation of $30 \%$ or less for 5 to 10 bioassays. Cherr et al. (1994) state that a CV of $35 \%$ or less indicates an acceptable level of repeatability for $\mathrm{EC}_{50}$ values. For bioassays with Ecklonia radiata, CVs for $\mathrm{EC}_{50}$ values ranged between 11 and $54 \%$. It is expected that variability estimates will fall within acceptable limits as reference testing is continued. When utilizing E. radiata for toxicity testing, monthly reference testing is recommended to monitor the conditions of the natural populations which are used as sources for zoospores.

The bioassays with Ecklonia radiata were not conducted over a long enough period to allow adequate comparison of temporal variability. However, this is an important aspect to consider and will be examined in a future study. Gunthorpe et al. (1995) observed seasonal variation in a fertilization assay with the brown alga Hormosira banksia, an effect attributed in part to 
increasing summer temperatures and stress upon this intertidal species. Anderson et al. (1990) also observed temporal variability in tests of copper which were conducted with Macrocystis pyrifera. They attributed this variation to factors such as seasonal fluctuation in the general health of the parent plants and levels of chelating compounds present in the dilution water.

\section{Endpoint comparison}

Growth of the germination tube was generally a more sensitive endpoint than germination alone, a trend which has been observed in other studies with macroalgae. Anderson et al. (1990) observed a similar trend in bioassays with Macrocystis pyrifera, but ultimately found sporophtye production (reproduction) to be the most sensitive of the endpoints examined. Garman et al. (1994) reported nuclear migration through the germination tubes of $M$. pyrifera zoospores was a significantly more sensitive endpoint than either germination or growth. Chung \& Brinkhuis (1986) found that germination of zoospores from Laminaria saccharina was the least sensitive of the endpoints they monitored in bioassays of copper, while growth of young sporophytes was most sensitive. Whilst endpoints which are more sensitive than germination and germ tube growth can be monitored, they may require a longer testing period or greater technical expertise to evaluate. As such, $48 \mathrm{~h}$ toxicity tests which monitor germination and growth of kelp zoospores may be more practical for routine testing (see also Thursby \& Steele 1995). Anderson et al. (1990) commented that while germination tube growth of $M$. pyrifera was more sensitive than germination, the ecological relevance of germination may be clearer; if zoospores do not germinate, they will not develop and no sporophyte recruitment will occur.

The difference in sensitivity to toxicants between germination and growth could be attributed to energetic or mechanistic factors. It appears that kelp zoospores rely on stored energy for germination and initial growth (Amsler \& Neushul 1991). It may take less energy to form the initial protrusion of the germination tube (and so qualify as germinated) than it does to reach the $10 \mu \mathrm{m}$ length which control E. radiata zoospores achieved in $48 \mathrm{~h}$. Zoospores may have a sufficient energy store to germinate with the added energetic cost imposed by the toxicant, but not enough to achieve germ tube growth which is comparable to controls. Pillai et al. (1992) have previously demonstrated that germination, germ tube elongation (growth) and nuclear division and migration were temporally and mechanistically distinct events in the early development of Macrocystis pyrifera gametophytes. Differ- ences in sensitivity between initial germination and germ tube growth may thus be due to the differential effect of toxicants upon the mechanisms (development of microtubules/microfilaments, formation of charge gradients; Anderson et al. 1990) associated with these phases.

\section{CONCLUSION}

Since sensitivities to a toxicant may vary among species, a suite of different organisms which represent a broad range of sensitivities should be used in a bioassay program (Rand et al. 1995). Ecklonia radiata is well suited for use in such a testing scheme since it has a wide distribution, is ecologically significant in nearshore benthic communities and has a comparatively simple bioassay methodology. Future studies to characterize seasonal variability, compare sensitivity between additional populations and examine the response to complex effluents will be undertaken to extend the existing toxicity database for this species.

Acknowledgements. The authors thank Mr Ken Gordon and Ms Jeannie Roper for their technical assistance and Ms Kirstin Ross for comments on initial drafts of the manuscript. This research was supported by an Australian Research Council (ARC) Small Grant.

\section{LITERATURE CITED}

Anderson BS, Hunt JW (1988) Bioassay methods for evaluating the toxicity of heavy metals, biocides, and sewage effluent using Macrocystis pyrifera (Agardh): a preliminary report. Mar Environ Res 26:113-134

Anderson BS, Hunt JW, Turpen SL, Coulon AR, Martin M (1990) Copper toxicity to mícroscopic stages of giant kelp Macrocystis pyrifera: interpopulation comparisons and temporal variability. Mar Ecol Prog Ser 68:147-156

Amsler CD, Neushul M (1991) Photosynthetic physiology and chemical composition of spores of the kelps, Macrocystis pyrifera, Nereocystis leutkeand, Laminaria farlowii, and Pterygophora californica (Phaeophyceae). J Phycol 27: 26-34

Burridge TR, Portelli T, Ashton P (1996) Effect of sewage effluents on germination of three marine brown algal macrophytes. Mar Freshwat Res 47:1009-1014

Cairns J Jr, Pratt JR (1989) The scientific basis of bioassays Hydrobiologia 188/189:5-20

Chagnon NL, Guttman SI (1989) Differential survivorship of allozyme genotypes in mosquitofish populations exposed to copper or cadmium. Environ Toxicol Chem 8:1141-1147

Cherr G, Dinnel P, Calwell R, Cardwell R, Chapman P (1994) Criteria for acceptable variability of marine chronic toxicity test methods. West Coast Marine Species Chronic Protocol Variability Study, BSAN report No. 2. Biomonitoring Science Advisory Board, Washington State Department of Ecology, Olympia, p 1-15

Chung IK, Brinkhuis BH (1986) Copper effects in early stages of the kelp, Laminaria saccharina. Mar Pollut Bull 17 $213-218$ 
Environment Canada (1990) Guidance document on control of toxicity test precision using reference toxicants. Environmental Protection Series, Report EPS 1/RM/12. Environment Canada

Garman GD, Pillai MC, Goff LJ, Cherr GN (1994) Nuclear events during early development in gametophytes of Macrocystis pyrifera, and the temporal effects of a marine contaminant. Mar Biol 121:355-362

Gunthorpe L, Nottage M, Palmer D, Wu R (1995) The development of a fertilisation inhibition bioassay using gametes of the brown alga Hormosira banksii. Australas J Ecotoxicol 1:25-31

Hall A, Fielding AH, Butler M (1981) Mechanisms of copper tolerance in the marine fouling alga Ectocarpus siliculous - evidence for an exclusion mechanism. Mar Biol 54:195-199

Hamilton MA, Russo RC, Thurston RV (1983) Trimmed Spearman-Karber method for estimating lethal concentrations in toxicity bioassays. Environ Sci Technol 11:714-718

Jennings R (1967) The development of the gametophyte and young sporophyte of Ecklonia radiata (C.Ag.) J.Ag. (Laminariales). J R Soc West Aust 50:93-96

Nevo E, Noy R, Lavie B, Beiles A, Muchtar S (1986) Genetic diversity and resistance to marine pollution. Biol J Linn Soc 29:139-144

Editorial responsibility: Otto Kinne (Editor),

Oldendorf/Luhe, Germany
Novaczek I (1984) Response of Ecklonia radiata (Laminariales) to light at $15^{\circ} \mathrm{C}$ with reference to the field light budget at Goat Island Bay, New Zealand. Mar Biol 80:263-272

Pillai MC, Baldwin JD, Cherr GN (1992) Early development in an algal gametophyte: role of the cytoskeleton in germination and nuclear translocation. Protoplasma 170:34-45

Rand GM, Wells PG, McCarty LS (1995) Introduction to aquatic toxicology. In: Rand GM (ed) Fundamentals of aquatic toxicology: effects, environmental fate, risk assessment, 2nd edn. Taylor and Francis, Washington, DC, p 3-67

Reed RH, Moffat L (1983) Copper toxicity and copper tolerance in Enteromorpha compressa (L.) Grev. J Exp Mar Biol Ecol 69:85-103

Richardson BJ, Martin M (1994) Marine and estuarine toxicity testing: A way to go? Additional sitings from Northern and Southern Hemsiphere Perspectives. Mar Pollut Bull 28: 138-142

Thursby GB, Steele RL (1995) Sexual reproduction tests with marine seaweeds (macroalgae). In: Rand GM (ed) Fundamentals of aquatic toxicology: effects, environmental fate, risk assessment, 2nd edn. Taylor and Francis, Washington, DC, $\mathrm{p} 171-188$

Zar JH (1984) Biostatistical analysis, 2nd edn. Prentice-Hall, Inc, Englewood Cliffs, NJ

Submitted: March 7, 1997; Accepted: December 12, 1997 Proofs received trom author(s): February 13, 1998 